\title{
Limited effects of a keystone species: trends of sea otters and kelp forests at the Semichi Islands, Alaska
}

\author{
Brenda Konar* \\ U.S. Geological Survey, University of California, Santa Cruz, California, USA
}

\begin{abstract}
Sea otters are well known as a keystone species because of their ability to transform sea urchin-dominated communities into kelp-dominated communities by preying on sea urchins and thus reducing the intensity of herbivory. After being locally extinct for more than a century, sea otters re-colonized the Semichi lslands in the Aleutian Archipelago, Alaska in the early 1990s. Here, otter populations increased to about 400 individuals by 1994 , but rapidly declined to about 100 by 1997 . Roughly 7 yr after initial otter re-colonization, there were only marginal changes in sea urchin biomass, mean maximum test size, and kelp density. These small changes may be the first steps in the cascading effects on community structure typically found with the invasion of a keystone species. However, no wholesale change in community structure occurred following re-colonization and growth of the sea otter population. Instead, this study describes a transition state and identifies factors such as keystone species density and residence time that can be important in dictating the degree to which otter effects are manifested.
\end{abstract}

KEY WORDS: Community structure - Trophic interactions · Urchin barrens · Enhydra lutris · Strongylocentrotus polyacanthus · Alaria fistulosa

\section{INTRODUCTION}

The various species that belong to an ecological community can assume diverse roles within the food web and competitive hierarchy, and will always rank very differently in their importance in structuring the community (Paine 1992, Mills et al. 1993, McCann et al. 1998). While there is clearly a gradient in the importance of species, a small number of species is often easily identified as occupying positions of particularly strong influence on community structure. These species often fill 1 of 2 mutually exclusive roles: dominant or keystone. Dominant species are ones in which densities or total biomass are very high, and for which community influence is a direct result of abundance. A keystone species is defined as one whose effect is dis-

-Present address: School of Fisheries and Ocean Sciences, University of Alaska Fairbanks, PO Box 757220, Fairbanks, Alaska 99775-7220, USA. E-mail: bkonar@ims.uaf.edu proportionately large relative to its abundance, and thus keystones are usually rare (Power et al. 1996).

Dominant species are commonly assumed to be of primary importance according to the bottom-up view of trophic interactions, which considers lower-level producers to have a primary role in structuring communities (see Hunter \& Price 1992, Power 1992 for reviews). This, however, is not always the case. A topdown view of trophic interactions may also characterize dominants as playing a controlling role in community structure. This is illustrated in systems where herbivores or omnivores are not limited by predation. In this case, animal abundances can increase, such that these organisms become important dominants, supplanting the controlling role of plants. Classic examples of such dominant species are sea urchins (Andrew \& Underwood 1993) and mussels (Paine 1974). In some systems, sea urchins can become so abundant that they overgraze attached plants in kelp forests, leaving what are commonly termed 'barren grounds' (areas devoid 
of macroalgae; Arnold 1976, Chapman 1981, Schiel 1982, Dean et al. 1984, Harrold \& Pearse 1987, Watanabe \& Harrold 1991), while mussels can form monocultures by outcompeting other sessile organisms for space (Paine 1974, Robles et al. 1995).

Members of a second group of important species have been labeled as keystones (sensu Paine 1969). By current definition, keystone species are comparatively rare in the communities in which they reside (Power et al. 1996). Keystone species have been identified in numerous ecosystems and at all trophic levels (see Mills et al. 1993, Power et al. 1996 for reviews). ln communities controlled by top-down forces, the keystones are often apex predators. These predators control their prey (often herbivores), which otherwise act as dominants, thereby exerting strong effects on community structure. The influence of keystone species is best seen by observing systems in which the keystone's population status is in flux, either through purposeful or fortuitous experiments. In this situation, a rise or fall in the keystone population abundance can cause cascading effects on its prey, their food species, and ultimately on the entire food chain (Fretwell 1987).

There has been a tendency in the ecological literature to apply the labels 'dominant' or 'keystone' to species wherever they occur. In fact, the evidence from nature indicates that these roles are highly context dependent (Foster 1990, Menge et al. 1994, Dean et al. 2000). The ability of a given species to exert a strong influence on a community structure (as either a dominant or a keystone) is dependent upon community composition and can be particularlý sensitive to conditions. For example, sea urchins may be dominant and capable of overgrazing attached macroalgae in one area while in another area or at a different time they have no dominant effect because of variation in factors such as food availability (Harrold \& Reed 1985), water movement (Ebeling et al. 1985), or population density (Andrew \& Underwood 1993). Similar contextdependent variation in the keystone effects of seastar (Menge et al. 1994) and lobster (Robles 1997) predation on intertidal mussels has been demonstrated for changes in wave exposure and sedimentation. With changes in these conditions, a potentially important species may quickly change from a minor player to one actively controlling community structure, and vice versa.

While such context dependence is recognized for some species, few studies have quantitatively addressed the factors that may limit the effect of a keystone species on community structure (except see Dean et al. 2000). In particular, it is not clear how sensitive the influences of keystone species are to internal factors such as the amount of time a species has been present in a community or to its density. By definition, the ef- fects exerted by a keystone species on community structure do not depend on high densities, but the extent to which community-wide effects of keystone species depend on the attainment of some critical density has not been carefully evaluated. Here these issues are addressed by examining the keystone role of sea otters Enhydra lutris in kelp forest communities in the Semichi Islands of the Aleutian Archipelago, Alaska.

The Semichi lsland group consists of 3 islands, Shemya, Nizki and Alaid (Fig, 1). Shemya Island $\left(52^{\circ} 43^{\prime} \mathrm{N}, 174^{\circ} 07^{\prime} \mathrm{E}\right)$ is the furthest east and largest of these 3 islands. The island has a shoreline of $22 \mathrm{~km}$. Nizki and Alaid are slightly smaller than Shemya and are attached to each other by a sand bar at low tide. There is approximately a $1.5 \mathrm{~km}$ wide channel between the islands of Shemya and Nizki. All 3 of these islands are exposed directly to swell and wave action from the Bering Sea to the north and the Pacific Ocean to the south.

\section{THE ALEUTIAN NEARSHORE ECOSYSTEM}

\section{Sea otter population status}

Sea otters were once abundantly distributed in coastal waters across the Pacific rim from Japan to central Baja, California (Kenyon 1969). By the early 1900s, the Pacific maritime fur trade had caused the local extinction of sea otters in most of the Aleutian Islands. Following their protection by the International Fur Seal Treaty in 1911, sea otters remnant at Rat Island recolonized the Rat Island group, and apparently

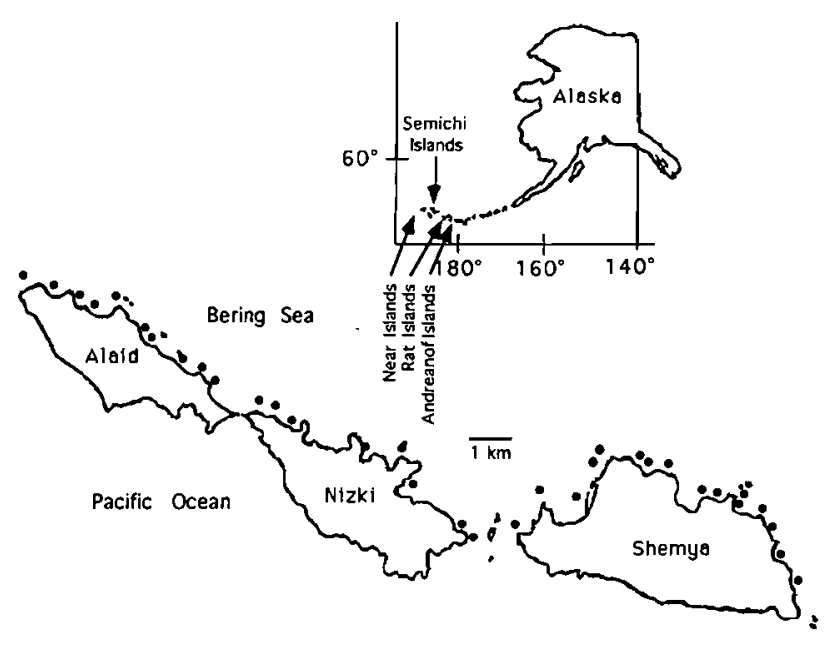

Fig. 1. Map of the Semichi Islands showing the location of Alaid, Nizki, and Shemya with dive iocations (๑). inset: map of Alaska showing the location of the Semichi Islands and neighboring island groups 
reached carrying capacity throughout this area by the 1950s. The Near Island group, about $225 \mathrm{~km}$ further west, did not become re-occupied until the mid-1960s, when a small number of sea otters re-colonized Attu Island. The sea otter population at Attu grew rapidly through the 1970s and 1980s (Estes 1990). Another Near Island, Agattu, was recolonized in the early 1980s. The Semichi Islands, approximately $30 \mathrm{~km}$ to the northeast, were recolonized in the early 1990s.

In the Aleutian Islands, sea otters are considered keystone species because of their influence as predators in kelp forest ecosystems (Estes \& Palmisano 1974, Estes et al. 1978, Estes \& Duggins 1995), where they can eat approximately 15 to $20 \%$ of their body mass daily (Kenyon 1969). Sea urchins Strongylocentrotus polyacanthus are a preferred prey of sea otters (Estes et al. 1981), and at high densities are capable of completely deforesting established kelp beds (Harrold \& Pearse 1987). While several other species consume sea urchins in the Aleutian Islands (e.g., sea stars and sea ducks), none of these appear to be capable of limiting urchin populations. Estes \& Duggins (1995) showed that on islands where sea otter density was high, sea urchin test diameters were relatively small and biomass low while algal cover was high. Conversely, on islands where sea otters were rare or absent, sea urchin test diameters were significantly larger and biomass higher while algal cover was low.

\section{Subtidal community structure}

Kelp forest communities in the western Aleutian archipelago contain a rich diversity of algal species (Lebednick \& Palmisano 1977). Surface canopies are formed by the large annual kelp Alaria fistulosa (Postels et Ruprecht). The most common understory kelps are the perennial brown algae Laminaria dentigera (Kjellman), L. yezoensis (Miyabe), Agarum cribrosum (Bory) and Thalassiophyllum clathrus (Gmelin; Postels et Ruprecht). Numerous species of foliose red algae occur beneath the understory kelp canopy. In areas where the perennial brown kelps dominate, sea urchins Strongylocentrotus polyacanthus are generally rare and small in size. Alternatively, in urchin-dominated zones, grazing has completely eliminated foliose algal cover, forming barren grounds. In these areas, encrusting coralline algae (mostly Clathromorphum spp. and Lithothamnium spp.) are the primary cover except for patches of the prostrate green alga Codium setchellii (Setchell et Gardner).

Kelp forests provide habitat for a diverse array of fish and invertebrates. Fish (including the Irish lords Hemilepidotus spp., greenlings Hexagrammos spp., and the rock sole Lepidopsetta bilineata; Ayres), bivalves (in- cluding the rock jingle Pododesmus macroschisma; Deshayes), chitons (including Katharina tunicata; Wood, and Cryptochiton stellen; Middendorf), limpets, crabs and seastars are all common inhabitants in this subtidal community. All of the above are known prey items of the sea otter in the Aleutians particularly when sea urchins are small or scarce (Estes et al. 1981, VanBlaricom \& Estes 1988).

Rocky subtidal habitats are patchy around the Semichi Islands. This leads to a patch mosaic of kelp forests and barren grounds. Course-grained sand surrounds most of these rocky outcroppings. No macroinvertebrates were found in these sandy areas (author's pers. obs.) because of the overall exposure to swell and currents. Also, no sea otters were ever observed foraging in these areas, probably due to the lack of invertebrates (author's pers. obs.).

\section{MATERIAL AND METHODS}

Sea otter population changes. Population counts of sea otters at the Semichi Islands were done during 4 years in a $10 \mathrm{yr}$ period (1987-1997) to determine their status and trends. Surveys were done in a single day by systematically searching the entire coastline of Alaid, Nizki, and Shemya Islands from small boats by at least 2 people using binoculars. This survey method was chosen because ground-truthing at other Aleutian Islands showed boat surveys to be efficient and accurate (Estes 1977, 1990; except see Udevitz et al. 1995 for Prince William Sound). These searches were usually done when sea states were very calm (low to moderate swell and no wind chop). One survey was done in both 1987 and 1994 and 2 surveys were done in each of 1995 and 1997. Within-year means were calculated for years in which multiple surveys were done.

Population counts, such as these, are naturally going to be biased low as some sea otters will always be missed by any method employed. However, the overall trends in population status will hold. Comparison of these population estimates to other areas should be done with caution, as different survey methods and locations will give varying degrees of bias.

Benthic community structure. To measure effects of changing sea otter densities at the Semichi Islands, benthic community structure was quantified both before sea otters became re-established (sometime in the late 1980s), several years later (1994) after otter numbers had increased, and then in 1997 as otter densities were declining. To quantify community structure, algal density and urchin biomass were examined at the same randomly chosen sites around each island in 1987, 1994 and 1997 (for methods of site determination and sampling details, see Estes \& Duggins 1995). Depending on 
the year, between 28 and 34 sites were surveyed at $7 \mathrm{~m}$ water depth and either 8 or 9 sites at $13 \mathrm{~m}$ water depth. Kelp densities were determined by counting the stipes in twenty $0.25 \mathrm{~m}^{2}$ quadrats at each site/depth combination. Placement of each individual quadrat was determined by a random number of kicks along a transect line. To determine sea urchin biomass, individuals were counted and collected from another set of randomly placed $0.25 \mathrm{~m}^{2}$ quadrats at each site. Urchins from any given site were sampled until at least 200 individuals were collected or 20 quadrats were surveyed. These urchins were taken to the surface, where their test diameters were measured to the nearest millimeter. Biomass was determined using these measurements and a linear model as in Estes et al. (1978). An overall mean maximum test diameter for each depth and year was determined by averaging the diameters of the largest urchin that was collected and measured in the previously described quadrats at each site.

Sea otter foraging behavior. To determine the primary food of sea otters, shore-based observations of feeding animals were undertaken periodically between June 1995 and June 1997 using a high powered Questar spotting scope. Following each dive, the type and number of the prey captured were recorded. A single foraging bout was defined as an unbroken sequence of dives made by 1 otter. The otters were watched until they stopped feeding, moved too far away to be observed or were joined by other otters making it difficult to distinguish them. To supplement these data, sea otter scats were examined on Shemya Island in the rocky intertidal from November 1995 to May 1997. On this island, otters haul out as a group during low tide at very specific sites (Estes et al. 1999). A total of 704 scats were examined during low tides after the otters had been hauled out of the water for at least approximately $2 \mathrm{~h}$. To assure this minimum surface time, once hauled out otters were located, the haul out sites were revisited a minimum of $2 \mathrm{~h}$ after the initial sighting. The scats were dissected in the field and the percent of each food item in the scat (by volume) was visually estimated.

\section{RESULTS}

\section{Sea ofter population changes}

The sea otter population in the Semichi Islands varied greatly between 1987 and 1997 (Fig. 2). From single surveys of all 3 islands, 1 otter was counted in 1987 and 390 (approximately 6.5 otters per $\mathrm{km}$ of shoreline) in 1994. Two surveys in both 1995 and 1997 documented a decline in the otter population. In 1995, 134.5 \pm 28.2 (mean $\pm 1 \mathrm{SE}$ ) otters were counted with a density

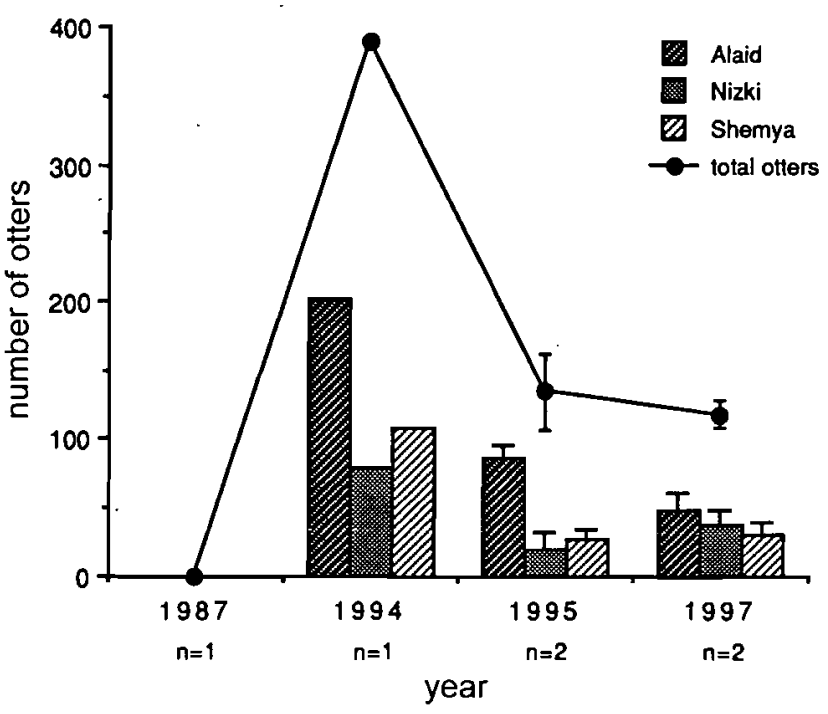

Fig. 2. Mean number of sea otters ( \pm 1 SE for 1995 and 1997) at Alaid, Nizki, Shemya, and all islands combined for 1987 , 1994, 1995, and 1997. Number of surveys conducted at each island is shown below the year

of 2.3 otters per $\mathrm{km}$ of shoreline. In $1997,118 \pm 10.0$ otters were counted with a density of 2.0 otters per km of shoreline. Based on these numbers, the total Semichi otter population declined by $65 \%$ between 1994 and 1995 and by an additional $16 \%$ between 1995 and 1997. In 1994 and 1995, otters were most abundant at Alaid, whereas in 1997, they were found to be equally abundant across all 3 islands.

\section{Benthic community structure}

During all years, sea urchin biomass appeared somewhat higher at $7 \mathrm{~m}$ water depth than at $13 \mathrm{~m}$, although a 2-way ANOVA showed that this was not statistically significant and there was no interaction (Fig. 3, Table 1). Also, there was no significant difference in sea urchin biomass between years (Fig. 3, Table 1). I am confident that the overall lack of differences found both between years and depths is real (power $=0.57$ and 0.99 for year and depth respectively). The differ-

Table 1. Two-way ANOVA of the effect of year $(1987,1994$, and 1997) and water depth (7 and $13 \mathrm{~m}$ ) on sea urchin biomass at randomly selected sites at the Semichi Islands

\begin{tabular}{|lcccc|}
\hline Source & df & MS & $F$-ratio & $\mathrm{p}$ \\
\hline Year & 2 & 105798 & 1.46 & 0.25 \\
Depth & 1 & 157346 & 2.11 & 0.15 \\
Year $\times$ Depti & 2 & 6535 & 0.09 & 0.92 \\
Error & 115 & 74544 & & \\
\hline
\end{tabular}




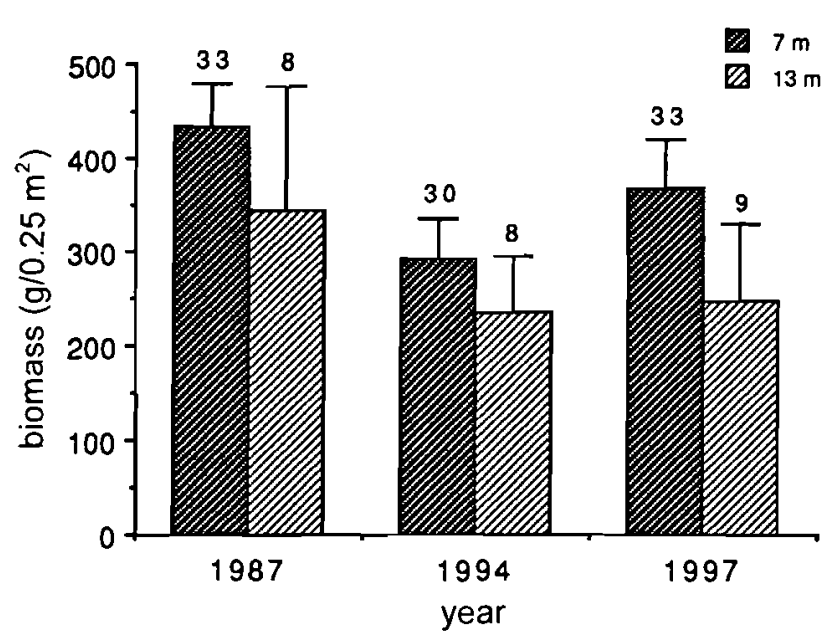

Fig. 3. Mean sea urchin biomass per $0.25 \mathrm{~m}^{2}(+1 \mathrm{SE})$ at the Semichi Islands for 1987, 1994, and 1997. Number of sites sampled is shown above standard error bars. No significant differences were found among years or water depths using a 2-way ANOVA

ence in biomass for each pair of sampling dates at each site was also calculated to determine the percentage of sites that had either an increase or decrease in biomass over time. While biomass at some sites increased and others decreased over each time interval (Fig. 4), the overall trend was a decline in biomass between 1987 and 1994. In contrast, the trend for urchin biomass between 1994 and 1997 was a slight but non-significant increase at $7 \mathrm{~m}$ and no discernible trend at $13 \mathrm{~m}$. The range in differences in the change of urchin biomass at $13 \mathrm{~m}$ was less than at $7 \mathrm{~m}$ (-900 to $+900 \mathrm{com}-$ pared to -1500 to +1200$)$; however, there were no significant differences between time interval distributions in sites that had varying changes in urchin biomass (1987 to 1994 and 1997 to 1997) within either depth (2-sample Kolmogorov-Smirnov test: for $7 \mathrm{~m}, \mathrm{p}=0.163$ and for $13 \mathrm{~m}, \mathrm{p}=0.801$ ).

The mean maximum test diameter of sea urchins changed significantly with year but not depth and there was a non-significant interaction (Fig. 5, Table 2). I am confident that the lack of significant dif-

Table 2. Two-way ANOVA of the effect of year $(1987,1994$, and 1997) and water depth $(7$ and $13 \mathrm{~m}$ ) on maximum mean sea urchin test diameters at randomly selected sites at the Semichi Islands

\begin{tabular}{|lcccc|}
\hline Source & df & MS & F-ratio & $\mathrm{p}$ \\
\hline Year & 2 & 847 & 8.74 & 0.00 \\
Depth & 1 & 175 & 1.81 & 0.18 \\
Year $\times$ Depth & 2 & 24 & 0.25 & 0.78 \\
Error & 111 & 97 & & \\
\hline
\end{tabular}
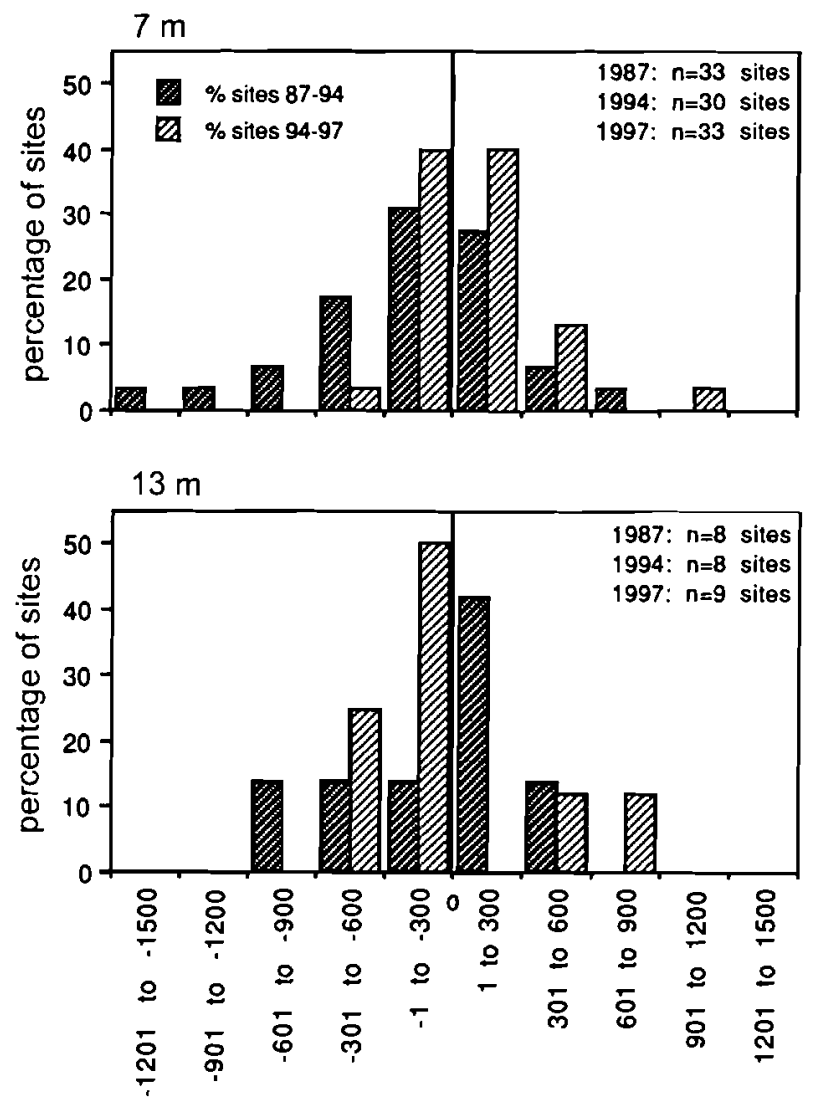

difference in sea urchin mean biomass $(\mathrm{g})$

Fig. 4. Change in sea urchin biomass for each of the sites over time. Net losses and gains were calculated from 1987 to 1994 and from 1994 to 1997 for all the Semichi Island sites combined at 7 and $13 \mathrm{~m}$

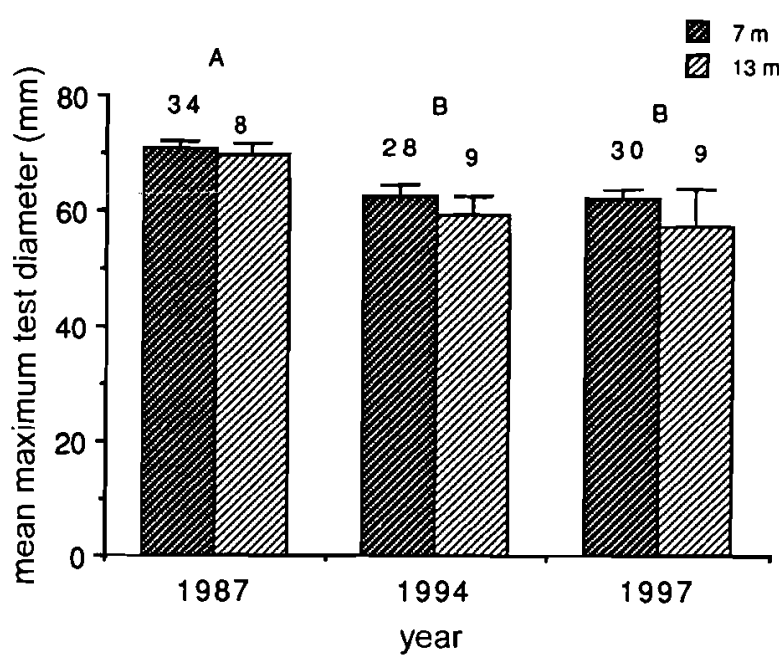

Fig. 5. Mean maximum sea urchin test diameter (+1 SE) at the Semichi Islands for 1987, 1994, and 1997. The number of sites sampled is shown above the standard error bars. There were no significant differences between depths. Similar letters above the standard error bars denote non-significant differences among years $(\mathrm{A}-\mathrm{B})$ using a post-hoc Scheffé $F$-test, $\mathrm{p}<$ 0.05 after a 2-way ANOVA 


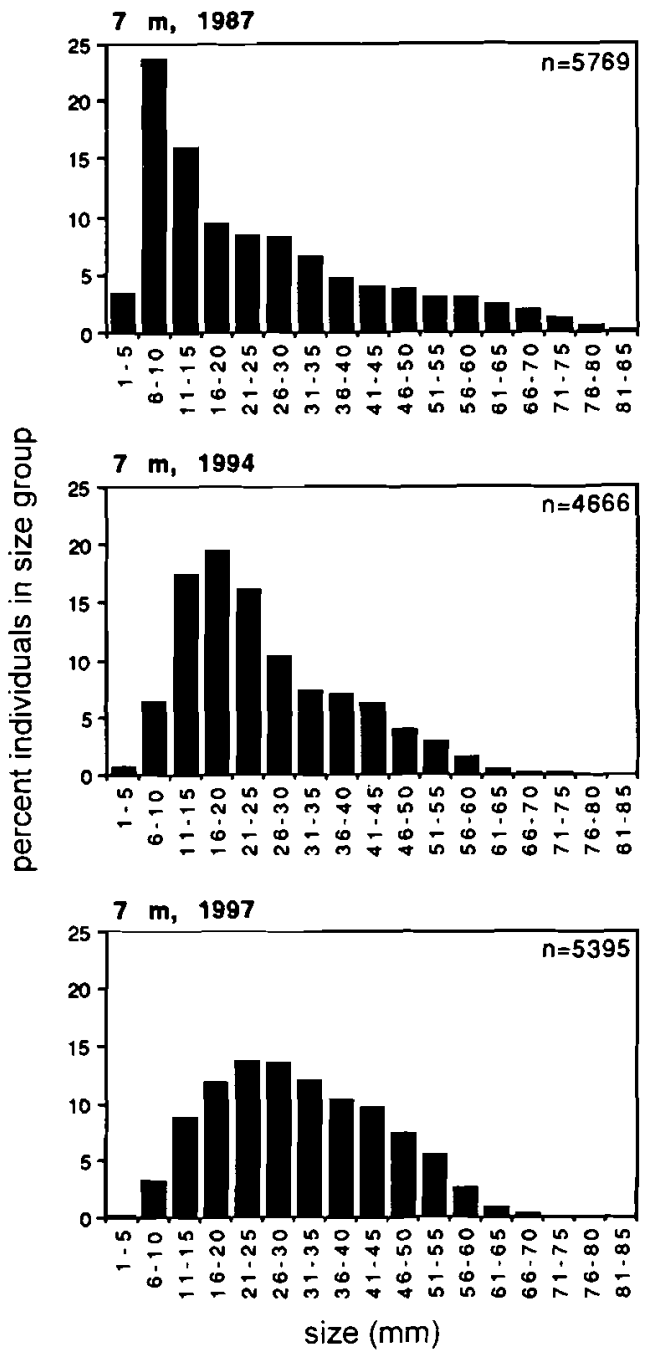

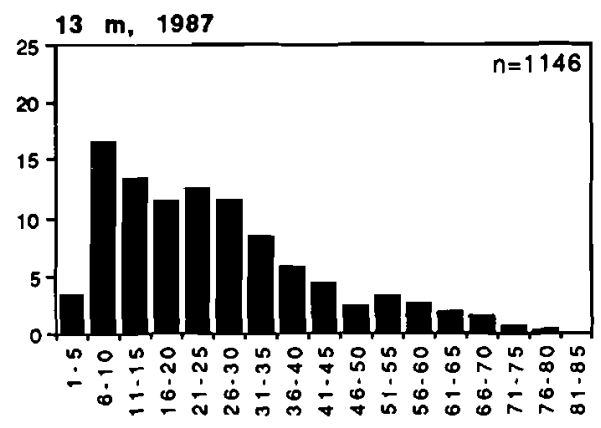
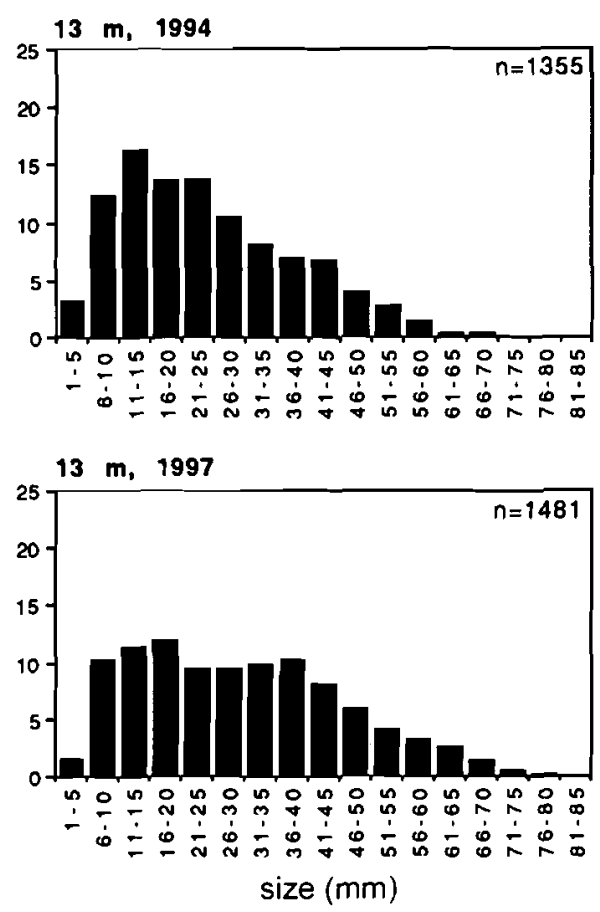

Fig. 6. Sea urchin sizefrequency distributions for the Semichi Islands in 1987, 1994, and 1997 at 7 and $13 \mathrm{~m}$ water depth ference between depths is real (power $=0.94$ ). At $7 \mathrm{~m}$ depth, mean maximum test size declined by $11.8 \%$ from 1987 to 1994 and by 3\% from 1994 to 1997 . Scheffé's post-hoc contrasts revealed that maximum test diameter was greater in 1987 than in either 1994 or 1997 and that the difference between the 2 later years was not significant (Fig. 5). At $13 \mathrm{~m}$ depth, mean maximum test size declined by $14.5 \%$ from 1987 to 1994 and by $3.7 \%$ from 1994 to 1997 . Over all dates, the test diameter of the largest sea urchins appeared slightly greater at the $7 \mathrm{~m}$ sites compared to the $13 \mathrm{~m}$ sites, but these differences were not significant (Table 2). Urchin size distributions varied over the study period. In 1987. many large urchins were present in addition to a peak in very small urchins at both depths (Fig. 6). These small urchins had test diameters of 6 to $10 \mathrm{~mm}$. In 1994 ( 7 yr later), this peak was at 16 to $20 \mathrm{~mm}$ in $7 \mathrm{~m}$ water depth and 11 to $15 \mathrm{~mm}$ in $13 \mathrm{~m}$ water depth. The largest urchins ( 76 to $85 \mathrm{~mm}$ test diameter) were missing in 1994 at both depths. In 1997, the size frequency was more even, with no perceivable peaks in size. During this year, few small or large urchins were found.

The only significant increase in kelp densities over time at the Semichi Islands was between 1987 and 1997 (Fig. 7), but this was marginally significant (2way ANOVA, $\mathrm{p}=0.0544$; Table 3 ). This lack of a large significant difference is due to low power (power = 0.21 ) caused by small effect size relative to the vari-

Table 3. Two-way ANOVA of the effect of year (1987, 1994, and 1997) and water depth ( 7 and $13 \mathrm{~m}$ ) on kelp stipe density at randomly selected sites at the Semichi Islands

\begin{tabular}{|lcccc|}
\hline Source & df & MS & F-ratio & $\mathrm{p}$ \\
\hline Year & 2 & 44.8 & 2.99 & 0.05 \\
Depth & 1 & 6.8 & 0.46 & 0.50 \\
Year $\times$ Depth & 2 & $\mathbf{2 . 4 9}$ & 0.17 & 0.85 \\
Error & 116 & 15.0 & & \\
\hline
\end{tabular}




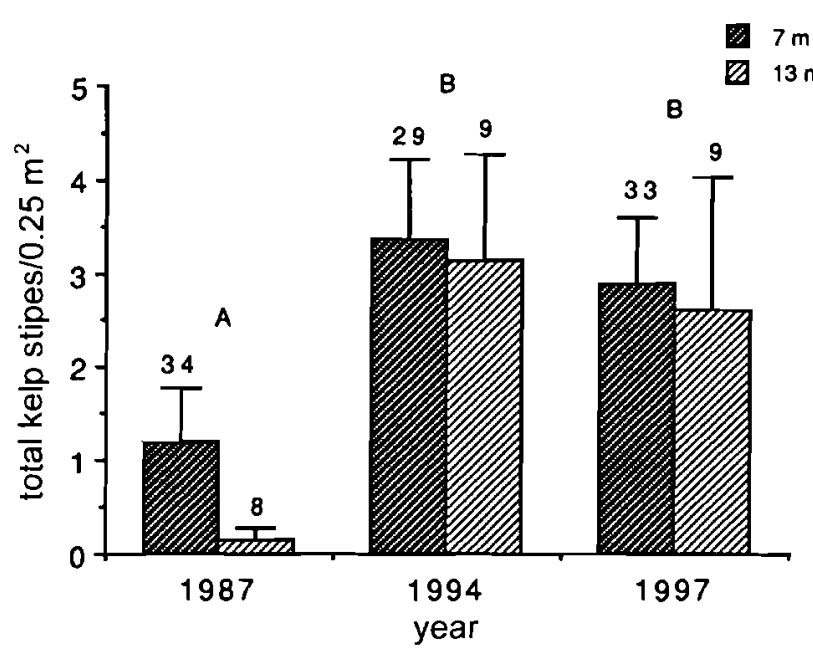

Fig. 7. Mean total number of kelp stipes per $0.25 \mathrm{~m}^{2}$ (+1 SE) at the Semichi Islands for 1987, 1994, and 1997. Number of sites sampled is shown above standard error bars. There were no significant differences between depths. Similar letters above the standard error bars denote non-significant differences among years $(\mathrm{A}-\mathrm{B})$ using a post-hoc Scheffé $F$-test, $\mathrm{p}<0.05$ after a 2-way ANOVA

ance in kelp density among plots. No significant differences were found between depths (power $=0.54$ ) and there was no interaction between year and depth. In general, overall kelp densities were lowest in 1987 (when otters were absent), highest in 1994 (when otter numbers were highest), and somewhat lower in 1997, when otter numbers were in decline (Fig. 7). Scheffé's post-hoc contrasts revealed that kelp density was lower in 1987 than in either 1994 or 1997 and that the 2 later years did not differ significantly (Fig. 7).

\section{Sea otter foraging behavior}

In total, 1518 sea otter foraging dives were observed, spread across 112 foraging bouts. Most of these dives were observed on the north side of Shemya Island because this was where most otters were found. Both direct foraging observations and scat data on Shemya Island showed that sea urchins were the otters' primary food item $(83.8 \%$ of foraging items and $94.7 \%$ of scat items). Other forage items included fish (Irish lords Hemilepidotus spp., the rock sole Lepidopsetta bilineata and one smooth lumpsucker Aptocyclus ventricosus), bivalves (including the rock jingle Pododesmus macroschisma), chitons (including Katharina tunicata and Cryptochiton stelleri), limpets, crabs and seastars. I observed otters eating seastars, which lack hard parts, but did not find seastar remnants in the scats. I also did not find chitons and limpets, which do have calcareous exoskeletons, in the scats. No prey items were found in the scats that also were not seen being consumed by otters during the foraging observations.

\section{DISCUSSION}

Some species can play an important role in structuring their communities. Their influences can vary among systems (Mills et al. 1993) and may be contextdependent within a system (Foster 1990, Menge et al. 1994, Robles 1997). This study of the effects of sea otters on subtidal communities at the Aleutian Islands is one of the first to present quantitative data suggesting that internal variables (density and residence time) may be influencing the effects or mediating the time required to see effects of keystone species (see also Dean et al. 2000).

The pattern involving keystone species in the nearshore subtidal community at the Semichi Islands differed from those of most other well-studied areas in the northern Pacific. In particular, a rapid, wholesale change in community structure (from urchin-dominated to kelp-dominated) was not observed with the re-establishment of the potential keystone species, the sea otter. This rapid rate of change is exemplified in some areas around Vancouver Island, British Columbia, where a change from an urchin-dominated to algal-dominated community occurred in under 6 mo following the re-establishment of sea otters (Watson 1993). When comparing the Semichi Islands to other study sites in the Aleutian Archipelago (Estes \& Palmisano 1974, Estes et al. 1978, Estes \& Duggins 1995), southeastern Alaska (Estes \& Duggins 1995), and British Columbia (Watson 1993), changes in the nearshore community structure at the Semichi Islands were limited. At the Semichi Islands, fluctuations in sea otter numbers were observed and were found to correspond with small changes in sea urchin biomass, mean maximum test diameters, and kelp stipe densities. However, these changes were limited when compared to other areas. An example of this is illustrated with kelp stipes. Although kelp stipe densities increased between 1987 and 1994 (Fig. 7), peak stipe densities achieved in the presence of otters were low when compared to other islands with abundant sea otters (i.e. where kelp stipe densities can reach over 15 per $0.25 \mathrm{~m}^{2}$ compared to a high of 3.5 per $0.25 \mathrm{~m}^{2}$ in this study; Estes \& Duggins 1995).

The data from the Semichi Islands suggest that the mere presence of a potentially keystone species is not enough to allow that species to fulfill the role of a classic keystone. This is supported by another study in Prince William Sound (Dean et al. 2000) that showed that the effects of reduced sea otter density on size distribution is predictable but that sea urchin biomass and the cascad- 
ing effects on the kelp community are less predictable. In other studies, a lack of a complete community modification by a keystone species has been attributed to various environmental factors, such as sedimentation and wave exposure (Menge et al. 1994, Robles 1997). In this study, the lack of community transformation was apparently due to non-environmental factors. One such factor that appears to be influencing this effect is keystone density. Although the definition of a keystone states that their influences are disproportionately large relative to their abundance, the data from this study suggest that the keystone phenomenon may require a threshold density. Although clear density dependence in the functional role of keystone species has not before been documented, it has been shown that some dominant species must reach a threshold density in order to cause a dramatic change in community structure (Andrew \& Underwood 1993). In Australia, when various densities of sea urchins were added to kelp stands, only the highest densities were capable of removing all the macroalgal cover. At the Semichi Islands, peak sea otter densities were approximately $6.5 \mathrm{~km}^{-1}$ in comparison to numbers for a neighboring island, Amchitka, where densities reached $32 \mathrm{~km}^{-1}$ in 1992 (J. A. Estes unpubl. data, using similar techniques to reduce sampling bias). Thus, it may be that otter density at the Semichis was not high enough to cause a dramatic change in the biomass of the dominant sea urchins.

At other islands in the Aleutians, sea otters have been shown to increase until food became limiting (Estes \& Duggins 1995). At the Semichi Islands, following an initial increase in sea otter population size, a decline was observed between 1994 and 1997, when my study was concluded. These relatively low numbers of sea otters never reached their theoretical carrying capacity (based on remaining food availability) before their abundances began to decline. When sea otters are food-limited they typically maintain a large prey diversity in their diet due to the scarcity of their preferred food sources (Estes et al. 1981). On Shemya Island, otters showed low diversity in their diet, feeding primarily on sea urchins (83.8\% of foraging observations and $95 \%$ of scat data). At Adak Island, where sea otters had reached carrying capacity, foraging data showed greater diversity in sea otter diet, including bivalves, fish, crabs and worms, although sea urchins remained important prey (33\%; Tinker \& Estes 1996). Other data also indicate that sea otters were not foodlimited at Shemya Island. First, sea urchin mean maximum test diameter and biomass remained relatively high even in 1994, at peak otter abundances. Previous work, which shows that otters preferentially feed on larger sea urchins (VanBlaricom \& Estes 1988), indicates that mean maximum sea urchin test diameters should have greatly decreased had otters become food-limited. Second, sea urchin biomass remained greatest in shallower water (Fig. 3). In other locations where sea otters have reached carrying capacity, sea urchin densities are greatly reduced in shallower depths ( 7 vs $13 \mathrm{~m}$; Estes et al. 1981) because foraging costs are less in shallower water and otters preferentially choose those depths. Based on the observation that the primary food item of sea otters was sea urchins during this period (direct observation of feeding otters and examination of scats), it appears that the decline in keystone density was not related to food limitation, implying that carrying capacity was never reached.

Similar to the Semichi Islands, there was another island in the western Aleutians (Attu) that did not exhibit a complete change from urchin-dominated to kelp-dominated after sea otters became re-established but before they reached their carrying capacity (Estes \& Duggins 1995). There were 2 notable differences between Attu and the Semichis. At Attu, although sea urchin densities were high, mean maximum test diameter was small. On this island, the sea otter population was increasing between the 1970s and early 1990, and had not yet reached its carrying capacity; however, sea otters were able to reduce the mean maximum size of the urchins (Estes \& Duggins 1995). This differs from the Semichis in that mean maximum test diameter at the Semichis was still large after the incomplete recovery of the otters and despite up to $5 \mathrm{yr}$ of otter residence. This implies that time of occupation (20 yr on Attu vs $5 \mathrm{yr}$ at the Semichis) might be influencing sea urchin populations. In another study in Prince William Sound Alaska, sea otters were absent for 9 yr but sea urchin biomass and kelp densities remained largely unchanged (Dean et al. 2000). The other noticeable difference between Attu and the Semichi Islands was that Attu had a fairly consistent recruitment of sea urchins (Estes \& Duggins 1995). These small urchins are capable of grazing much of the algal cover and probably assisted in maintaining the barren state of the community. This did not occur during my study at the Semichi Islands as small urchins were rare between 1995 and 1997 (author's pers. obs.). Many small urchins were found at these islands in 1987 (Estes \& Duggins 1995), so it seems that urchin recruitment at the Semichi Islands may be episodic.

It appears that the abundance of sea otters in the Semichi Islands began to decline before they reached numbers sufficient to reduce sea urchin densities and relax grazing pressures on the algal community. This situation is mirrored at other islands in the Aleutian Archipelago where sea otter abundances have also declined through the 1990s (Estes et al. 1998). One hypothesis for this reduction in the sea otter population is the possible addition of a higher trophic level keystone predator, the killer whale. Estes et al. (1998) 
found that the decline in the sea otter population on Adak Island was coincident with the decline of kelp beds. Areas that contained dense kelp beds are now devoid of most foliose macroalgae. At the Semichi Islands, there was a $70 \%$ decline in the sea otter population between 1994 and 1997. Surprising, only 1 otter carcass was found on the beach during the time of the decline (Estes et al. 1999). The cause of reduction in sea otters at the Semichi Islands is unknown but may also be a consequence of enhanced killer whale predation. Although killer whales were never observed feeding on sea otters at Shemya Island, they were occasionally sighted in the nearshore environment (author's pers. obs). This reduction in sea otters is probably not due to otter emigration because females with pups were observed every year, suggesting year round occupancy as opposed to overall population movements (Estes et al. 1999).

In this study, the density and occupation time of a keystone species were shown to be possible explanations for the lack of an overall community change. At the Semichi Islands, sea otters were unable to generate a substantial cumulative effect on the nearshore benthic community after $5 \mathrm{yr}$ of residence. In particular, they were unable to achieve large reductions in the overall mean maximum test size and shallow-water densities of the sea urchins. Although keystone species have been defined as those whose effect is disproportionately large relative to their abundance (Power et al. 1996), it appears that a threshold of abundance and time must be reached to result in strong cascading community effects.

Acknowledgements. This project was funded by the Department of Defense, Legacy Resource Management Program. the USGS-Biological Resources Division, and the National Science Foundation. Much of the data is from on-going studies by J. Estes. I would like to thank J. Estes, D. Doak, P. Raimondi, E. Joules, S. Kohin, and D. Monson for offering comments that greatly improved a previous version of this manuscript. I would also like to thank my primary field assistants: C. Roberts and C. Dominic. Many thanks also go to $\mathrm{M}$. Kenner (U. C. Santa Cruz), G. Augustine and J. Copeland (DoD), and J. Bodkin, D. Monson, and G. Esslinger (USGSBiological Resources Division, Anchorage) for informal support. Thanks also need to go to the US Fish and Wildlife Service-Alaska Maritime Refuge and the US Coast Guard for logistical support.

\section{LITERATURE CITED}

Andrew NL, Underwood AJ (1993) Density-dependent foraging in the sea urchin Centrostephanus rodgersï on shallow subtidal reefs in New South Wales, Australia. Mar Ecol Prog Ser 99:89-98

Arnold DC (1976) Local denudation of the sublittoral fringe by the green sea urchin, Strongylocentrotus droebachiensis (O. F. Muller). Can Field-Nat 90:186-187
Chapman ARO (1981) Stability of sea urchin dominated barren grounds following destructive grazing of kelp in St. Margaret's Bay, Eastern Canada. Mar Biol 62:307-311

Dean TA, Schroeter SC, Dixon JD (1984) Effects of grazing by two species of sea urchins (Strongylocentrotus franciscanus and Lytechinus anamesus) on recruitment and survival of two species of kelp (Macrocystis pyrifera and Pterygophora californica). Mar Biol 78:301-313

Dean TA, Bodkin JL, Jewett SC, Monson DH, Jung D (2000) Changes in sea urchins and kelp following a reduction in sea otter density as a result of the Exxon Valdez oil spill. Mar Ecol Prog Ser 199:281-291

Ebeling AW, Laur DR, Rowley RJ (1985) Severe storm disturbances and reversal of community structure in a southern California kelp forest. Mar Biol 84:287-294

Estes JA (1977) Population estimates and feeding behavior of sea otters. In: Merritt ML, Fuller RJ (eds) The environment of Amchitka lsland, Alaska. US Energy Research and Development Administration, Springfield, VA, p 526

Estes JA (1990) Growth and equilibrium in sea otter populations. J Anim Ecol 59:385-401

Estes JA, Duggins DO (1995) Sea otters and kelp forests in Alaska: generality and variation in a community ecological paradigm. Ecol Monogr 65:75-100

Estes JA, Palmisano JF (1974) Sea otters: their role in structuring nearshore communities. Science 185:1058-1060

Estes JA, Smith NS, Palmisano JF (1978) Sea otter predation and community organization in the western Aleutian Islands, Alaska. Ecology 59:822-833

Estes JA, Jameson RJ, Johnson AM (1981) Food selection and some foraging tactics of sea otters. In: Chapman JA, Pursley D (eds) Worldwide Fubearer Conference Proceedings, Vol 1. University of Maryland Press, Baltimore, MD, p 606-641

Estes JA, Tinker MT, Williams TM, Doak DF (1998) Killer whale predation on sea otters linking oceanic and nearshore ecosystems. Science 282:473-476

Estes JA, Konar BK, Tinker MT (1999) Sea otter population biology and subtidal community ecology at Shemya Island, Alaska. Final report for Department of Defense Legacy Project Nos. 9401280 and 9510014

Foster MS (1990) Organization of macroalgal assemblages in the Northeast Pacific: the assumption of homogeneity and the illusion of generality. Hydrobiologia 192:21-33

Fretwell SD (1987) Food chain dynamics: a central theory in ecology? Oikos 50:291-301

Harrold C, Pearse JS (1987) The ecological role of echinoderms in kelp forests. In: Jangoux M, Lawrence JM (eds) Echinoderm studies. AA Balkema, Rotterdam, p 137-233

Harrold C, Reed DC (1985) Food availability, sea urchin grazing, and kelp forest community structure. Ecology 66: 1160-1169

Hunter MD, Price PW (1992) Playing chutes and ladders: heterogeneity and the relative roles of bottom-up and topdown forces in natural communities. Ecology 73:724-732

Kenyon KW (1969) The sea otter in the eastern Pacific Ocean. N Am Fauna 68:1-352

Lebednick PA, Palmisano JF (1977) Ecology of marine algae. In: Merritt ML, Fuller RJ (eds) The environment of Amchitka Island, Alaska, US Energy Research and Development Administration, Springfield, VA, p 353-393

McCann K, Hastings A, Huxel GR (1998) Weak trophic interactions and the balance of nature. Nature 395:794-798

Menge BA, Berlow EL, Blanchette CA, Navarrette SA, Yamada $S B$ (1994) The keystone species concept: variation in interaction strength in a rocky intertidal habitat. Ecol Monogr 64:249-286 
Mills SL, Soule ME, Doak DF (1993) The keystone-species concept in ecology and conservation. Bioscience 43: $219-224$

Paine RT (1969) A note on trophic complexity and community stability. Am Nat 103:91-93

Paine RT (1974) Intertidal community structure: experimental studies on the relationship between a dominant competitor and its principal predator. Oecologia 15:93-120

Paine RT (1992) Food-web analysis through field measurement of per capita interaction strength. Nature 355:73-75

Power ME (1992) Top-down and bottom-up forces in food webs: do plants have primacy? Ecology 73:733-746

Power ME, Tilman D, Estes JA, Menge BA, Bond WJ, Mills LS, Daily G, Castilla JC, Lubchenco J, Paine RT (1996) Challenges in the quest for keystones. Bioscience 46: 609-620

Robles CD (1997) Changing recruitment in constant species assemblages: implications for predation theory in intertidal communities. Ecology 78:1400-1414

Robles CD, Sherwood-Stephens R Alvarado M (1995) Responses of a key intertidal predator to varying recruitment of its prey. Ecology 76:565-579

Editorial responsibility: Charles Peterson (Contributing Editor), Morehead City, North Carolina, USA
Schiel DR (1982) Selective feeding by the echinoid, Evichinus chloroticus and the removal of plants from subtidal algal stands in northern New Zealand. Oecologia 54:379-388

Tinker T, Estes JA (1996) The population ecology of sea otters at Adak Island, Alaska. Final Report (12/96) Natural Resources Section/Code 23/KL Engineering Field Activity, NW Naval Facilities Engineering Command, Poulsbo Washington

Udevitz MS, Bodkin JL, Costa DP (1995) Detection of sea otters in boat-based surveys of Prince William Sound, Alaska. Mar Mamm Sci 11:59-71

VanBlaricom GR, Estes JA (1988) The community ecology of Sea Otters. Springer-Verlag, Berlin

Watanabe JM, Harrold C (1991) Destructive grazing by sea urchins Strongylocentrotus spp. in a central California kelp forest: potential roles for recruitment, depth, and predation. Mar Ecol Prog Ser 71:125-141

Watson J (1993) The effects of sea otter (Enhydra lutris) foraging on shallow rocky communities off northwestern Vancouver Island, British Columbia. PhD thesis, University of California, Santa Cruz, CA

Submitted: June 28, 1999; Accepted: January 11, 2000 Proofs received from author(s): June 5, 2000 